\title{
Chemical Control of Root-Knot Nematodes in Established Vineyards
}

\author{
J. T. LOUBSER AND C. A. DE KLERK
}

Viticultural and Oenological Research Institute, Private Bag X5026, 7600 Stellenbosch, Republic of South Africa.

Submitted for publication: April 1985

Accepted for publication: June 1985

Keywords: Nematodes, Meloidogyne, control, established vineyards

\begin{abstract}
Chemical control of root-knot nematodes (Meloidogyne spp.) in established vineyards was investigated. A liquid soil fumigant (1,3-dichloropropene) and four systemic (nonfumigant) nematicides in granular form, viz. aldicarb, carbofuran, oxamyl and fenamiphos were applied as soil treatments during bud burst and after harvest. Significant average yield and cane mass increases were recorded during the three years following split treatment at bud burst with aldicarb and oxamyl and when aldicard was applied as a single treatment after harvest.
\end{abstract}

The introduction of DBCP (1,2-dibromo3-chloropropane) in the mid-1950's as a non-phytotoxic chemical for the control of nematodes on perennial crops, was welcomed by all grape producers. Its application in established vineyards became a standard recommendation in the U.S.A. (Raski, Hart \& Kasimatis, 1965) and in Australia many vineyards were treated successfully with this nematicide (Meagher, 1969). Field trials regarding the effectiveness of DBCP were also carried out in South Africa (Smith, Giliomee \& De Klerk, 1973). However, in 1977 DBCP was found to have carcinogenic and mutagenic properties and its use was suspended in the U.S.A. because of the risk to public health. Since then many attempts have been made throughout the world to find a satisfactory alternative. A number of non-fumigant, systemic nematicides including fenamiphos (Nemacur), aldicarb (Temik), oxamyl (Vydate) and carbofuran (Curaterr, Furadan) have been tested on grapevines (Rajendran \& Naganathan, 1978; Atilano \& Van Gundy, 1979; Cuany et al., 1979; Cuany, Lavergne \& Pistre, 1980; Raski, et al., 1981; Stirling, 1982). Although these chemicals provide excellent nematode control on a number of crops, field trials on grapevines have not yielded consistent results and at present no nematicide is registered in South Africa for use on established vineyards.

To determine the efficacy of chemicals to replace DBCP for the control of nematodes in established vineyards, several field trials were conducted in the Vaalharts irrigation area in the northern Cape Province. This paper reports results obtained from the two initial trials.

\section{MATERIAL AND METHODS}

Two trials were conducted in a seven year old ungrafted Colombar vineyard on a sandy soil with severe root-knot nematode (Meloidogyne incognita and Meloidogyne javanica) infestation. Trial plots, each consisting of seven adjacent vines in a row, were grouped into replicates according to uniformity of growth.

Treatments were replicated five times and data collected annually from the five vines in the centre of each plot. In trial A, treatments were applied as a single application at a given dosage, whilst in trial $\mathrm{B}$ two applications were given 30 days apart, half the dosage at a time.
The following treatments were included:

Trial A: Single application either at bud burst (September) or post harvest (February).

1. Control.

2. Aldicarb (15\%) at a dosage of $5 \mathrm{~kg}$ ai / ha at bud burst.

3. Aldicarb $(15 \%)$ at a dosage of $5 \mathrm{~kg}$ ai $/ \mathrm{ha}$ at post harvest.

4. Carbofuran $(10 \%)$ at a dosage of $10 \mathrm{~kg}$ ai $/$ ha at bud burst.

5. Fenamiphos (10\%) at a dosage of $10 \mathrm{~kg}$ ai $/$ ha at bud burst.

6. Oxamyl $(10 \%)$ at a dosage of $10 \mathrm{~kg}$ ai $/$ ha at bud burst.

7. 1,3-Dichloropropene (75\%) at a dosage of $125 \ell /$ ha at bud burst.

Trial B: Split application at bud burst (September) and 30 days later (October).

1. Control.

2. Aldicarb (15\%) at a dosage of $2,5 \mathrm{~kg}$ ai $/$ ha per application.

3. Carbofuran $(10 \%)$ at a dosage of $5 \mathrm{~kg}$ ai $/$ ha per application.

4. Fenamiphos (10\%) at a dosage of $5 \mathrm{~kg}$ ai/ha per application.

5. Oxamyl $(10 \%)$ at a dosage of $5 \mathrm{~kg}$ ai/ha per application.

6. 1,3-Dichloropropene (75\%) at a dosage of $62,5 \ell /$ ha per application.

Granular formulations were applied by hand in a one metre wide strip on both sides of the vine row and disced into the top $10 \mathrm{~cm}$ of soil. 1,3-Dichloropropene was injected into the soil at a depth of $20 \mathrm{~cm}, 30 \mathrm{~cm}$ apart, using a hand injector pump. Immediately after application, the vineyard was flood irrigated.

The experiment was initiated in 1980 and the treatments were repeated annually until 1983 . Yield and cane mass were determined before application and for three consecutive years thereafter. Soil samples for nematode analysis were collected before and one year after the initial treatment. Nematodes were extracted from $250 \mathrm{~cm}^{3}$ aliquots of soil using the Oostenbrink elutriator/sugar flotation technique. In the present studies on nematode control in established vineyards, nematode population numbers were 
not used for evaluating treatments. The nematicides were evaluated by measuring their effect on grapevine yield and growth. All results were subjected to a two-way analysis of variance.

\section{RESULTS AND DISCUSSION}

No significant reduction in root-knot or other nematode populations was recorded one year after treatment (data not shown). According to Raski et al. (1981) the reduction of nematode numbers following treatment with aldicarb, carbofuran, ethoprop and fenamiphos continues for a period of 150 to 200 days only before the population increases once again. Nematode suppression can also be assessed on gall density as done by Rajendran \& Naganathan (1978). These workers found evidence of nematode control when numbers of galls per $\mathrm{g}$ of roots were assessed three months after treatment with aldicarb, carbofuran and DBCP, but it is not known whether this will still be evident after one year. Nematode suppression for short periods during active root growth of vines may, however, be sufficient to result in increased growth and yield.

Results of the single applications with respect to yield and growth are shown in Table 1.

Yield and cane mass for plots before treatment (1980) did not differ statistically because of the pre-selection of trial plots. Post-treatment increases recorded annually for both yield and cane mass showed great variation between replicates which may be the reason why treatments did not differ significantly from the control.

As reported by others (Raski et al., 1981; Stirling, 1982) the results of field trials are often disappointing and inconsistent because of the great variability in vegetative growth and nematode distribution from vine to vine. In order to overcome these phenomena the current trials were therefore also evaluated on the basis of average yield and cane mass measured over the full treatment period and not on annual measurements only. Percentage change between pre- and post-treatment periods is given.
The average post-treatment yield and cane mass for 1,3dichloropropene were significantly less than the control. Aldicarb applied during autumn was the only treatment which resulted in a significant yield and cane mass improvement $(P \leqslant 0,10)$. Calculated on the percentage change between the average pre-treatment and posttreatment yield and cane mass, aldicarb resulted in a marked improvement compared to the control. Carbofuran, fenamiphos, oxamyl and 1,3-dichloropropene treạtments all yielded significantly lower average cane masses compared to the control. Because of a different pruning practice the pre-treatment cane masses are not directly comparable with those of post-treatment figures. All data vines were pruned uniformly but more severely at commencement of the experiment because too many bearers were left during the preceding year, hence the general decline in the cane masses recorded in subsequent years.

Results of the split applications are shown in Table 2.

Pre-treatment yield and cane mass did not differ significantly. Aldicarb and oxamyl gave a significant improvement of average yield over the three year period. Both these treatments also had significantly higher yields than the control in the third year, whilst oxamyl also had a significantly higher yield in the second year following treatment $(P \leqslant 0,10)$.

According to the average post-treatment cane mass figures, the same two treatments, viz. aldicarb and oxamyl, as well as fenamiphos, gave better results than the control. On an annual basis, however, none of the treatments provided a statistically significant improvement when compared to the control. The percentage change calculated for yield and cane mass for the split application was higher than for a single application of the same chemical. With the exception of 1,3-dichloropropene all split treatments resulted in an improved yield compared to the control. All but 1,3-dichloropropene and carbofuran resulted in an improved growth of treated vines.

The lower yield gains recorded during 1983 may be attributed to very dry and hot conditions, but the drastic

TABLE 1

Effect of an annual single application of nematicides during bud burst or post-harvest on the yield and growth of a root-knot infested ungrafted Colombar vineyard at Vaalharts

\begin{tabular}{|c|c|c|c|c|c|c|c|c|c|c|c|c|}
\hline \multirow{3}{*}{ Treatment } & \multicolumn{6}{|c|}{ Yield $(\mathrm{kg} / 5$ vines) } & \multicolumn{6}{|c|}{ Cane mass (kg/ 5 vines) } \\
\hline & \multirow{2}{*}{$\begin{array}{c}\begin{array}{c}\text { Pre- } \\
\text { treatment }\end{array} \\
1980\end{array}$} & \multicolumn{3}{|c|}{$\begin{array}{l}\text { Change in yield } \\
\text { after treatment }\end{array}$} & \multirow{2}{*}{$\begin{array}{c}\text { Average } \\
\text { post-treatment } \\
\text { yield mass }\end{array}$} & \multirow[t]{2}{*}{$\begin{array}{c}\text { Change } 1 \\
(\%)\end{array}$} & \multirow{2}{*}{\begin{tabular}{|c|}
$\begin{array}{c}\text { Pre- } \\
\text { treatment }\end{array}$ \\
1980
\end{tabular}} & \multicolumn{3}{|c|}{$\begin{array}{l}\text { Change in cane mass } \\
\text { after treatment }\end{array}$} & \multirow{2}{*}{$\begin{array}{c}\text { Average } \\
\text { post-treatment } \\
\text { cane mass }\end{array}$} & \multirow[t]{2}{*}{$\begin{array}{c}\text { Change } 1 \\
(\%)\end{array}$} \\
\hline & & 1981 & 1982 & 1983 & & & & 1981 & 1982 & 1983 & & \\
\hline Control & 25,32 & 9,10 & 20,32 & 0,12 & 35,17 & $+38,9$ & 5,60 & $-1,08$ & $-1,78$ & $-2,14$ & 3,93 & $-29,8$ \\
\hline Aldicarb (15\%g) (bud burst) & 24,02 & 9,54 & 25,56 & $-1,26$ & 35,30 & $+47,0$ & 4,10 & $-0,14$ & $-0,80$ & $-1,08$ & 3,43 & $-16,3$ \\
\hline Aldicarb ( $15 \% \mathrm{~g})$ (post harvest) & 25,86 & 14,56 & 33,92 & 14,78 & $46,95 *$ & $+81,6$ & 4,60 & $+0,40$ & $+0,68$ & $-0,02$ & $4,91^{*}$ & $+6,74$ \\
\hline Carbofuran $(10 \% \mathrm{~g})$ & 22,78 & 5,28 & 16,80 & 1,24 & 30,55 & $+34,1$ & 4,18 & $-0,52$ & $-1,44$ & $-1,78$ & $2,93^{*}$ & $-29,9$ \\
\hline Fenamiphos $(10 \% \mathrm{~g})$ & 23,92 & 5,46 & 15,56 & $-4,48$ & 29,33 & $+23,1$ & 4,82 & $-1,36$ & $-1,92$ & $-2,40$ & $2,93^{*}$ & $-39,3$ \\
\hline Oxamyl $(10 \% \mathrm{~g})$ & 23,44 & 0,14 & 17,68 & $-3,06$ & 28,36 & $+21,0$ & 3,58 & $-0,84$ & $-0,52$ & $-1,24$ & $2,71^{*}$ & $-24,3$ \\
\hline 1,3-Dichloropropene (75\% fumliq) & 24,20 & 6,46 & 2,34 & $-15,44$ & $21,99 * *$ & $-9,1$ & 4,43 & $-1,78$ & $-2,54$ & $-3,26$ & $1,89 * *$ & $-57,3$ \\
\hline LSD: $P \leqslant 0,10^{*}$ & 19,35 & 18,37 & 20,85 & 21,80 & 10,67 & & 2,29 & 1,57 & 2,17 & 2,43 & 0,98 & \\
\hline LSD: $P \leqslant 0,05^{* *}$ & 22,88 & 20,51 & 23,73 & 24,81 & 12,76 & & 2,52 & 1,78 & 2,39 & 2,77 & 1,17 & \\
\hline
\end{tabular}

Calculated on average pre- and post-treatment figures. 
TABLE 2

Effect of an annual split application of nematicides during bud burst on the yield and growth of a root-knot infested ungrafted Colombar vineyard at Vaalharts

\begin{tabular}{|c|c|c|c|c|c|c|c|c|c|c|c|c|}
\hline \multirow{3}{*}{ Treatment } & \multicolumn{6}{|c|}{ Yield (kg/ 5 vines) } & \multicolumn{6}{|c|}{ Cane mass ( $\mathrm{kg} / 5$ vines) } \\
\hline & \multirow{2}{*}{$\begin{array}{c}\begin{array}{c}\text { Pre- } \\
\text { treatment }\end{array} \\
1980\end{array}$} & \multicolumn{3}{|c|}{$\begin{array}{l}\text { Change in yield } \\
\text { after treatment }\end{array}$} & \multirow{2}{*}{$\begin{array}{c}\text { Average } \\
\text { post-treatment } \\
\text { yield mass }\end{array}$} & \multirow[t]{2}{*}{$\begin{array}{c}\text { Change }^{1} \\
(\%)\end{array}$} & \multirow{2}{*}{\begin{tabular}{|c|}
$\begin{array}{c}\text { Pre- } \\
\text { treatment }\end{array}$ \\
1980
\end{tabular}} & \multicolumn{3}{|c|}{$\begin{array}{c}\text { Change in cane mass } \\
\text { after treatment }\end{array}$} & \multirow{2}{*}{$\begin{array}{c}\text { Average } \\
\text { post-treatment } \\
\text { cane mass }\end{array}$} & \multirow[t]{2}{*}{$\begin{array}{c}\text { Change }^{1} \\
(\%)\end{array}$} \\
\hline & & 1981 & 1982 & 1983 & & & & 1981 & 1982 & 1983 & & \\
\hline Control & 13,28 & 6,68 & 14,94 & 6,72 & 22,72 & $+71,1$ & 1,60 & 0,60 & 0,66 & 0,80 & 2,28 & $+42,5$ \\
\hline Aldicarb $(15 \% \mathrm{~g})$ & 13,76 & 9,18 & 24,48 & $23,20 *$ & $31,61 * *$ & $+129,7$ & 2,02 & 1,26 & 2,02 & 1,68 & $3,68 * *$ & $+82,2$ \\
\hline Carbofuran $(10 \% \mathrm{~g})$ & 13,62 & 6,26 & 21,42 & 18,94 & 29,16 & $+114,1$ & 2,02 & 0,30 & 0,92 & 0,98 & 2,75 & $+36,1$ \\
\hline Fenamiphos $(10 \% \mathrm{~g})$ & 11,72 & 6,94 & 20,32 & 16,42 & 26,28 & $+124,2$ & 1,90 & 0,74 & 1,38 & 0,88 & $2,90 * *$ & $+52,6$ \\
\hline Oxamyl $(10 \% \mathrm{~g})$ & 12,70 & 5,88 & $29,38 *$ & $25,50^{*}$ & $34,05^{* *}$ & $+168,1$ & 1,88 & 1,44 & 1,28 & 1,34 & $3,23 * *$ & $+71,8$ \\
\hline 1,3-Dichloropropene (75\% fumliq) & 14,36 & 6,62 & 11,24 & 10,00 & 23,65 & $+64,7$ & 1,98 & 0,40 & 0,78 & 0,56 & 2,56 & $+29,3$ \\
\hline LSD: $P \leqslant 0,10^{*}$ & 5,62 & 8,18 & 14,23 & 14,94 & 6,94 & & 1,30 & 1,23 & 1,47 & 1,31 & 0,51 & \\
\hline LSD: $P \leqslant 0,05^{* *}$ & 7,39 & 9,44 & 16,02 & 17,25 & 8,29 & & 1,42 & 1,35 & 1,58 & 1,42 & 0,61 & \\
\hline
\end{tabular}

'Calculated on average pre- and post-treatment figures.

yield reduction $(29,1 \%)$ of the control is more typical of nematode damage under conditions of stress. The lower yield reduction of treated plots $(3,3 \%$ to $12,2 \%)$ against the control is indicative of successful treatment. It is evident that single applications of carbofuran, fenamiphos, oxamyl and 1,3-dichloropropene caused reductions in yield and growth compared to split applications. This may be attributed to phytotoxicity of the higher dosages applied at single applications. McKenry \& Kearny (1982) also reported that 1,3-dichloropropene can reduce vigor and yield of established vineyards.

The cost-effectiveness of the aldicarb and oxamyl treatments appears promising. Statistically significant average yield improvements of $97 \%$ and $58,6 \%$ respectively were obtained with oxamyl and aldicarb as split applications against $42,7 \%$ with a single application of aldicarb during autumn.

\section{CONCLUSIONS}

Nematode control in established vineyards is subject to a high degree of variation. This is especially true for smaller plots as utilised in these two trials. It is therefore recommended that future experiments be conducted on a larger scale which should include several hundred vines per treatment. However, significant improvements were demonstrated by these trials and certain promising visual observations were made.

Results of the two field trials indicate that a split application is more effective than a single application in spring. Percentage change in yield recorded for split treatments showed a definite increase for all but one nematicide tested.

Aldicarb and oxamyl appear to be the most effective nematicides when applied as split treatments during spring. An improvement in yield will not become apparent in the first year following treatment but improved growth of the vines may be obtained.
As a single treatment, aldicarb, especially when applied during autumn, was the only chemical which led to an improvement in both yield and cane mass. These findings suggest that an autumn application will be more effective than one in spring and further trials are currently running to substantiate this.

No significant reduction of nematode populations was recorded during these trials. In view of the positive results obtained in terms of yield and cane masses with certain nematicides, it seems appropriate to monitor nematode populations at shorter intervals after application in order to clarify this phenomenon.

\section{LITERATURE CITED}

ATILANO, R. A. \& VAN GUNDY, S.A., 1979. Effects of some systemic non-fumigant and fumigant nematicides on grape mycorrhizae fungi and citrus nematode. Pl. Dis. Reptr 63, 729-733.

CUANY, A., LAVERGNE, J. C., TRUEL, P. \& RENNES, C., 1979. Activité relative de quelques nématicides dans la lutte contre le nématode Meloidogyne arenaria de Vitis vinifera. Le Progr. Agric. Vitic. 96, 430-432.

CUANY, A., LAVERGNE, J. C. \& PISTRE, R., 1980. Action nématicide de l'aldicarbe et du sulfocarbe contre le nématode Xiphinema index en vignoble. Le Progr. Agric. Vitic. 97, 126-129.

McKENRY, M. V. \& KEARNEY, C., 1982. Soil fumigants as replacements for DBCP in vineyards. (Abstr.) J. Nematology 14, 457.

MEAGHER, J. W., 1969. Nematodes and their control in vineyards in Victoria, Australia. Int. Pest Control 11, 14-18.

RAJENDRAN, G. \& NAGANATHAN, T. C., 1978. Control of rootknot nematodes in grapes. Vitis 17, 271-273.

RASKI, D. J., HART, W. H. \& KASIMATIS, A. N., 1965. Nematodes and their control in vineyards. Calif. Agric. Exp. Stn. Serv. Circ. $533,1-23$.

RASKI, D. J., JONES, N. O., HAFEZ, S. L., KISSLER, J. J. \& LUVISI, D. A., 1981. Systemic nematicides tested as alternatives to DBCP. Calif. Agric. May - June, 11-12.

SMITH, P. C., GILIOMEE, J. H. \& DE KLERK, C. A., 1973. Response of established vineyards to nematode control with dibromochloropropane. Phytophylactica 5, 115-118.

STIRLING, G. R., 1982. Nematicides in vineyards: possible alternatives to DBCP. Australian Grapegrower and Winemaker. April, 85. 